\title{
DESIGN OF STATE \\ CONTROL REGULATIONS IN MINERAL MINING VALUE ADDED ACTIVITIES
}

\author{
Akmaluddin Rachim \\ Center for Energy and Mining Law Studies \\ akmaluddin@gmail.com
}

\begin{abstract}
The Constitutional Court has given the Constitutional Court the interpretation of state control or the right to control as a guide in mineral mining governance activities. The problem arises when this estimate has not been able to be properly implemented in mineral mining governance arrangements. The presence of Law no. 3 of 2020 which is expected to have implications for the greatest possible prosperity of the people with the presence of a form of full state control in activities to increase added value has not been able to answer this problem. This study aims: (1) to determine whether the regulation of the concept of state control has been accommodated in value added activities as regulated in Law no. 3 of 2020, (2) to determine the appropriate design for the concept of state control to achieve the goal of state control. This research is a normative legal research. The research was conducted by means of a literature study that examines primary and secondary legal materials and uses a conceptual approach. The data that has been collected were analyzed using descriptive qualitative methods. The results of this study concluded that: (1) Regulation of the concept of state control has not been accommodated in value added activities as regulated in Law no. 3 of 2020. Even the right to control the state as interpreted by the Constitutional Court tends to be ignored. (2) The regulatory design for the concept of state control that is appropriate for achieving the goal of state control is that it must have a strong legal and institutional substance and have a vision for Indonesia's industrialization in the future. The substance of the law must refer to the mandate of Article 33 paragraph 3 of the 1945 Constitution and the sustainable institutional management model.
\end{abstract}

Keywords: Regulation, Mineral Minig Value, Institutional.

\section{Journal History}

Received

September 16, 2020;

Reviewed

: October 12, 2020;

Accepted

October 28, 2020;

Published

November 1, 2020

Copyright @2020 NLR. All right reserved. 


\section{INTRODUCTION}

The concept of state procurement in the fields of natural resources, especially mineral and coal has actually been formulated through Constitutional

Court No. 001-021-022 / PUU-I / 2003 on Judicial Law No. 22 of 2001 on Oil and Gas of the Law Constitution of 1945. In subsequent developments, the Constitutional Court (MK) provided a new interpretation of the concept of state control through the Constitutional Court Decision Number 3 / PUU-VIII / 2010 concerning Judicial Review of Law Number 27 of 2007 concerning Management of Coastal Areas and Small Islands against the Law Basic.

Dialetics towards the interpretation of state control did not stop after the $a$ quo decision was made. In subsequent developments, this interpretation undergoes metamorphosis. Through the Decision of the Constitutional Court Number 36 / PUU-X / 2012 concerning Review of Law Number 22 Year 2001 regarding Oil and Natural Gas against the Constitution, the Court has provided a new interpretation. Their taf $\mathrm{s}$ ir recently signaled that efforts to achieve the greatest prosperity of the people. ${ }^{1}$

The development of the interpretation of state control suggests that in order to

${ }^{1}$ Article 33 paragraph 3 of the 1945 Constitution of the Republic of Indonesia achieve the greatest possible prosperity for the people, an interpretation of Article 33 paragraph 3 of the Constitution is needed which is relatively easy to implement. Because so far, policies towards efforts to achieve people's welfare are still difficult to apply in the form of concrete and measurable programs.

In the legal politics of mineral and coal mining business activities, there are actually provisions that regulate efforts to achieve the greatest prosperity of the people, namely through activities to increase added value. Activities to increase the added value is done through the activities of refining and / or processing of the results of the mineral and coal. Recently, there are provisions

regarding coal development and / or utilization activities which are thought to provide the greatest benefit for the welfare of the people. ${ }^{2}$

Processing activities are intended as an effort to improve the quality of Mineral mining commodities to produce products with physical and chemical characteristics that do not change from the nature of the original mining commodity for refining or becoming industrial raw materials. ${ }^{3}$ Meanwhile refining activities are an effort to improve the quality of mineral mining commodities through physical and chemical processes as well as further

\footnotetext{
${ }^{2}$ Article 1 paragraph 6 Law no. 3 of 2020

${ }^{3}$ Article 1, paragraph 20 of Law no. 3 of 2020
} 
refining processes to produce products with different physical and chemical properties from original mining commodities to metal products as industrial raw materials. ${ }^{4}$

As for activities related to the development and / or utilization of coal, it is an effort to improve the quality of coal with or without changing the physical or chemical properties of the original coal. ${ }^{5}$ This provision at a glance shows that the processing and / or refining and development and / or utilization activities as regulated in Law No.3 of 2020 are efforts to increase added value which are expected to have the greatest implications for the welfare of the people.

The problem arises when the political policy of increasing added value is faced with the concept of state control as previously described. Of course it needs to be assessed by looking at the overall and conformity political content of mineral mining law and coal through Law No . 3 of 2020 .

\section{METHOD}

This research is a normative legal research. Marzuki in Eka NAM Sihombing (2019) states that the normative juridical legal research method is a method that uses an approach that is based on the main legal material by examining theories, 3 of 2020

${ }^{4}$ Article 1 paragraph 20a Law no.

${ }^{5}$ Article 1 paragraph $20 \mathrm{~b}$ of Law no. 3 of 2020

${ }^{6}$ Eka N.A.M Sihombing, Eksistensi Paralegal dalam Pemberian Bantuan Hukum concepts of legal principles, norms, rules of legislation, court decision, agreement. The nature of the research used in this paper is prescriptive, adhering to the characteristics of legal science as an applied science, the prescriptions given in legal research activities must be able and possible to be applied (Marzuki, 2011). Therefore what is produced by legal research, even if it is not a new legal principle or a new theory, is at least a new argument. ${ }^{6}$

The research was conducted by means of literature study or using secondary data with several approaches, such as reviewing the 1945 Constitution of the Republic of Indonesia, Law no. 3 of 2020, Constitutional Court Decision, Academic Paper on the Draft Law concerning Amendments to Law Number 4 of 2009 concerning Mineral and Coal Mining and the Problem Inventory List (DIM) of the Draft Law on Amendments to Law No. 4 of 2009 concerning Mineral and Coal Mining in 2019 and uses a conceptual approach. The data that has been collected were analyzed using descriptive qualitative methods.

\section{DISCUSSION}

\section{Settings Concepts Country Control in Law No. 3 of 2020}

Pancasila as the philosophy of life of the nation which is also the

bagi Masyarakat Miskin (The Existence of Paralegals in Providing Legal Aid to the Poor), Jurnal Ilmiah Penegakan Hukum, Vol. 6, No. 1, June(2019). 
source of all legal sources has highdimensional values and is in accordance with the values that live in society, because Pancasila is also a national character that can distinguish Indonesian people from other nations so that Pancasila also becomes a reference against various rules which are then followed by the constitution and various other organic regulations. The 5th precept "Social justice for all Indonesians", if interpreted, can be a fundamental foundation for the existence of rights and obligations between regional heads who provide LKPJ to the DPRD to achieve justice for the people at the regional level in upholding transparency and accountability towards the implementation of regional government. $^{7}$

In principle, the concept and objectives of state control have been regulated in the 1945 Constitution. Article 33 paragraph 3 of the 1945 Constitution states that "the earth and water and the natural resources contained therein shall be controlled by the state and used for the greatest prosperity of the people". By the Constitutional Court, the right to control by the state has been given interpretation. This interpretation can be seen in several decisions of the Constitutional Court related to

\footnotetext{
7 Cynthia Hadita, Regional Autonomy Political Politics Of Regional Liability Reports To Regional Representatives In The Implementation Of Local Government, Nomoi Law Review, Volume 1, Issue 1, May 2020, p. 91.
}

judicial review of the natural resources

sector. This interpretation serves as a reference to provide parameters and definitions related to the state's right to control as regulated in the Constitution.

The Constitutional Court as a state institution that functions as the guardian and interpreter of the constitution has provided its interpretation through the Constitutional Court Decision No.001-021-022 / PUU-I / 2003. According to Hamdan Zoelva (Chairman of the Constitutional Court for the period 2013-2015), there are three meanings to the concept of state control rights. ${ }^{8}$ These three meanings include: first, controlled by the state when the state exercises regulatory power (regelendaad), administers (bestuuradaad), manages (beheersdaad), supervises (toezichthoedensdaad), which refers to the Constitutional Court Decision 001-021-022 / PUU-I / 2003.

The second meaning, the most important element of state control is "for the greatest prosperity of the people" with four benchmarks, namely: first, the benefit of natural resources for the people. Second, the level of distribution of benefits of natural resources for the people. Third, the level of people's

8 Hamdan Zoelva, Memaknai Putusan MK No. 111/PUU-XIII/2015 Tentang Ketenagalistrikan. Disampaikan saat acara Focus Group Discussion (FGD) Kologium Jurist Institute, Hotel Grand Sahid Jakarta, (8 Mei 2019). 
participation in determining the benefits of natural resources. Fourth, respect for the people's right from generation to generation in utilizing natural resources, based on the Constitutional Court Decision No. 3 / PUU-VIII / 2010.

The third meaning is to achieve the goal of state control, namely "for the greatest prosperity of the people", then the form of state control is ranked based on the state's ability. In the first place, the state carries out direct management of natural resources. Second, the state makes policies and administrations. In third place, the state conducts regulation and supervision, which refers to the provisions of the Constitutional Court Decision No. 36 / PUU-X / 2012.

The

interpretation of "controlled by the state" by the Constitutional Court clearly explained the necessity for the full presence of the state in the power to make policies, carry out management, regulation, management and supervision. What must be controlled by the state is if: (i) the production branches are important for the state and affect the livelihoods of the people; (ii) important for the state but does not affect the livelihoods of the people; or (iii) not important for the state but controlling the livelihoods of the people. The three of them must be controlled by the State and controlled as much as possible for the prosperity of the people.
With this interpretation, policy makers must have understood the parameters or scope of the scope of the state's right to control as regulated in the constitution. Mining administrative activities must lead to the greatest achievement of the people's welfare and the transformation of natural resources for human development.

\section{Arrangement of Control Concept to Achieve State Goals through Value Added Activities in Law No. 4 of 2009 and Act No . 3 of 2020.}

The Constitutional Court has formulated an interpretation of the concept of state control. This interpretation has become a reference in the management of Natural Resources, especially in relation to implementing the state tenure rights policy in the mineral mining sector. Nevertheless the interpretation of the concept of state control speckle $m$ able to be implemented by the volitional act and decision of the Court .

Academic Manuscript Draft Law on the Amendment of Act No. 4 of 2009 on Mineral and Coal states that $\mathrm{p}$ ermasalahan that often arise in the implementation of Law No. 4 of 2009 on Mineral and Coal Mining is the provision of processing and refining. ${ }^{9}$ Law No. 4 of 2009 requires all mining companies to build smelters. The construction of a smelter is intended so that the results of mining business activities are processed and refined to improve

9 Ibid, p. 83. 
the quality of minerals and / or coal and to utilize and obtain associated minerals. The management and refining of these processing and refining activities must be controlled by the state in order to provide real added value to the national economy. The added value has il activities of processing and refining is one embodiment of the implementation of the rights of state control as utilized for the welfare of the people and serving the people.

Therefore, with reference to the sociological grounding in academic texts, it is obvious to mention that a major problem in the governance of mining activities have not been able to implement the right of state control over natural resources through processing and refining.

In fact, processing and refining activities provide a marked increase in added value to the national economy . The maximum economic value and strategic value can be obtained if processing and refining are carried out in the country as mandated in Law Number 4 of 2009 concerning Mineral and Coal Mining (Minerba Law). Domestic processing and refining is an effort to increase added value so that mineral and coal mining products spur national economic growth.

The condition of natural resource management, particularly in the mineral mining sector in Indonesia, has been in the form of raw materials for decades until now,

10 Elucidation to Article 102 states that the added value in this provision is intended to increase the final without prior domestic processing and refining. This condition results in mineral resources not generating added value or a multiplier effect directly on the people as expected and guaranteed in the 1945 Constitution of the Republic of Indonesia.

The management and utilization of mineral resources must be linked to the nature of these natural resources which are not renewable. This means that one day, if it continues to be exploited, it will certainly run out. As a non-renewable natural resource and various types of mineral mining, sooner or later one day it will become scarce or even cannot be found. Even though the existence of these natural resources in Indonesia has not been optimally felt by the people. With such conditions, the political law that must be determined by the DPR and the Government is to optimize the increase in added value through processing and refining activities .

\section{Processing and Refining Regulations in Law No. 4 of 2009}

Processing and refining required as stipulated in Article 102 of Law No. 4 of 2009 . The article, saying that "holders of IUP and IUPK obliged to increase the added value of mineral resources and / or coal in the implementation of mining, processing and refining, as well as minerals and coal utilization." ${ }^{10}$ Furthermore, it is

product of the mining business or the utilization of associated minerals. 
emphasized in Article 103 of the Minerba Law which states:

(1) Holders of IUP and IUPK Production Operations are obliged to carry out processing and refining of mining products domestically; ${ }^{11}$

(2) Holders of IUP and IUPK as referred to in paragraph (1) can process and refine mining proceeds from other IUP and IUPK holders; and

(3) Further provisions regarding the increase in added value as referred to in Article 102 as well as processing and refining as referred to in paragraph (2) shall be regulated in a government regulation.

The

two $a$

quo regulations explain that holders of mining business permits and special mining business permits are required to increase the added value of mineral and / or coal resources when carrying out mining, processing and refining and utilization, as well as in the domestic business. This is intended because mineral and coal as a non-renewable natural resource which is a national asset controlled by the state - then all mining business activities must truly provide benefits to the people and increase state revenue. The description refers to the principle of mineral and coal mining operation which is mandatory, as it is stated that Minerba mining is managed based on the principles

11 Elucidation of Article 103 paragraph (1) The obligation to carry out domestic processing and refining is intended, among other things, to increase of: benefit, justice and balance; side with the interests of the nation; participatory, transparent and accountable; and sustainable and environmentally friendly.

Provisions concerning the activities of processing and refining confirmed back in Article 170 of the Mining Law, b ahwa "holders of contracts of work referred to in Article 169 that are already in production are required to conduct purification as referred to in Article 103 paragraph (1) no later than 5 (five) years since the Act-This law is promulgated. Article a quo is an alarm so that the obligation of entrepreneurs to carry out processing and refining of Minerba is carried out in accordance with the applicable provisions.

Of such provisions, the policy of increasing the added value of mineral and coal - through processing and refining in the country - as stipulated in Article 102 and Article 103 and Article 170 of the Mining Law, s already appropriate to the needs of the Indonesian nation. Given the current state of mineral resource management, most of them are still exported in the form of raw minerals which do not have a broad impact on the Indonesian people .

More than that, the Constitutional Court emphasized that the domestic processing and refining policies contained in the Minerba Law were also appropriate and

and optimize the mining value of products, availability of industrial raw materials, absorption of labor, and increase state revenue. 
constitutional, as stated in

the Constitutional

Court decision Number 10 / PUU-XII / $2014 .^{12}$ This was clearly stated in the consideration of its decision, the Constitutional Court was of the opinion:

"Whereas because minerals and coal are one of the important production branches for the state and control the lives of many people, based on the mandate of the 1945 Constitution, the legislators form the Minerba Law which in the preamble (considering) letters $a$ and $b$ of Law 4/2009 states: that minerals and coal contained in the Indonesian mining jurisdiction are nonrenewable natural resources as gifts from God Almighty who have an important role in fulfilling the lives of many people, therefore their management must be controlled by the State to provide added value significantly to the economy nationwide in an effort to achieve prosperity and welfare of the people in an equitable

manner; That mineral and coal mining business activities which are mining business activities other than geothermal, oil and natural gas and groundwater have an important role in giving added value significantly to national economic growth and

${ }^{12}$ Constitutional Court Decision Number 10 / PUU-XII / 2014, p. 171. sustainable

development; Whereas

because mining products, which include mineral and coal resources, are natural resources controlled by the state, the state has the right to regulate mineral and coal resources aimed at the greatest prosperity of the people. The regulatory function by the state can be carried out through legislative powers by the DPR and the President or through regulatory authorities by the Government, one of which is regulation through the formation of Government Regulations and Ministerial Regulations. Control by the state over mineral and coal resources means that the state is authorized and given the freedom to regulate and make policies related to the use of mineral and coal resources with constitutional measures, namely "for the greatest welfare of the people."

These considerations clearly explain that the state has the right to regulate mineral and coal resources for the benefit of the people's welfare and prosperity. In another part, the Minerba Law also states clearly that the objectives of Minerba management, as regulated in Article 3 of the Minerba Law, include:

a. ensure the effectiveness of the implementation and control of mining business activities in an 
efficient, effective and competitive manner;

b. guarantee the benefits of mineral and coal mining in a sustainable and environmentally friendly manner; ensure the effectiveness of the implementation and control of mining business activities in an efficient, effective and competitive manner;

c. guarantee the benefits of mineral and coal mining in a sustainable and environmentally friendly manner; guarantee the availability of minerals and coal as raw materials and / or as energy sources for domestic needs;

d. support and develop national capabilities so that they are more able to compete at the national, regional and international levels;

e. increase the income of local communities, regions, and countries, as well as create jobs for at-large welfare of the people; and

f. guarantee legal certainty in the implementation of mineral and coal mining business activities.

So it is thus very clear in Law no. 4 of 2009 and the Constitutional Court Decision Number 10 / PUU-XII / 2014 said that processing and refining activities must be carried out. Therefore, all business activities related to mineral and coal mining must comply with the applicable legal provisions. With so be useful in the life of society, nation and support national development.

\section{Regulations for processing and / or refining in Law no. 3 of 2020 .}

Provisions for processing and / or refining activities in Law 3 of 2020 are different from Law no. 4 of 2009. In Law no. 3 of 2020, the provisions regarding processing and refining are differentiated. Phrases for processing and / or refining become optional, alternative phrases. Even though in the a quo law the phrase is an alternative, it is necessary to examine the regulation further. Whether it will have implications for mengura ng i degrees of state control or not. The following is a description of the articles in Law no. 3 of 2020 .

Article 102 of Law no. 3 of 2020 states that:

(1) Holders of IUP or IUPK at the stage of Production Operation activities are required to increase the added value of Minerals in Mining Business activities through:

a. Processing and refining of metal mineral mining commodities;

b. Processing for non-metal mineral mining commodities; and / or

c. Processing for rock mining commodities.

(2) Holders of IUP or IUPK at the stage of Production Operation activities may carry out the Development and / or Utilization of Coal.

(3) Increasing the added value of Minerals through Processing and / or Purification activities as 
referred to in paragraph (1) must meet the minimum requirements for Processing and / or Purification, taking into account, among others:

a. increase in economic value; and / or

b. market needs.

(4) Further provisions regarding the minimum limit of Processing and / or Purification are regulated by or based on Government Regulation.

Article 103 says that:

(1) Holders of IUP or IUPK at the stage of Mineral Production Operation activities as referred to in Article 102 are obliged to carry out Processing and / or Purification of Minerals from Mining domestically.

(2) In the event that the IUP or IUPK holder at the Production Operation stage of activity has carried out Processing and / or Purification as referred to in paragraph (1), the Government shall guarantee the sustainability of the utilization of Processing and / or Purification products.

Article 104 explains that:

(1) Holders of IUP or IUPK at the stage of Production Operation activities as referred to in Article 103 can carry out Processing and / or Purification by themselves in an integrated manner or in collaboration with:

a. holders of IUP or other IUPK at the stage of Production Operation activities that have integrated Processing and / or Purification facilities; or b. other parties that carry out Processing and / or Purification business activities that are not integrated with mining activities whose licenses are issued based on the provisions of the statutory regulations in the industrial sector .

(2) Holders of IUP or IUPK during the Production Operation activity stage as referred to in Article 103 may carry out cooperation in the Development and / or Utilization of Coal with other IUP or IUPK holders during the Production Operation activity stage, or other parties carrying out Coal Development and / or Utilization activities. .

Urain regarding the provisions for processing and / or refining as regulated in Law no. 3 of 2020 implies that the degree of right to control or control of the state will decrease. In addition, this provision provides facilities for foreign companies or private companies in mining governance. Mining businessmen castrate state power over natural resources through the $a$ quo law. This provision also shows that the state is more subject to the wishes of entrepreneurs in providing investment incentives. Padaha when compared to the benefits obtained, of course this is more profitable for the entrepreneur.

Other provisions in Law No. 3 of 2020 which clearly reduce and even tend to delegitimize state control rights in activities to increase added value are seen in Article 170A. Article 170A states that: 
(1) Holders of KK, Production Operation IUP, or Metal Mineral Production Operation IUPK who:

a. has carried out Processing and Purification activities;

b. in the process of building Processing and / or Purification facilities; and / or

c. have collaborated in Processing and / or Purification with holders of Production Operations IUP, other Production Operations IUPK, or Production Operations IUP specifically for Processing and Purification or other parties that carry out Processing and / or Purification activities, may sell certain unrefined metal mineral products abroad within a maximum period of 3 (three) years since this law comes into force. ${ }^{13}$

This provision indicates the existence of treason, neglect, denial and denial of the mandate of the founding father which has been formulated in Article 33 paragraph (3) of the Constitution and reduces the 'right to control the state' which has been interpreted by the Constitutional Court. Of course, this provision deserves to be revoked because it is not in accordance with. M esk ipun the Problem Inventory List (DIM) Draft Law on Amendments to the Law No. 4 of 2009 concerning

13 Inventory List of Problems (DIM) Draft Law on Amendments to Law No. 4 of 2009 concerning Mineral and Coal Mining of 2019, No. 912, p. 131, states that this policy has been running and is only given until 2022 with sufficient conditions stipulated in
Mineral and Coal Mining of 2019 proposed by the Government - states that this policy is an activity that has been ongoing and is limited to a period of only until 2022.

This policy is still contrary to the mandate in the 1945 Constitution and the Constitutional Court Decision. This provision is a clear violation of the constitution and mutatis mutandis in the future, it is necessary to make changes. Thus, the regulation of value added activities in Law no. 3 of 2020 ignores the mandate of the constitution.

Design of the Right Concept and Arrangement of State Control to Achieve the Goals of State Control .

The concept of state control that is appropriate and can lead to the achievement of state objectives is a policy that has a broad impact on mining governance activities. One of the concepts that can be applied in achieving the country's goals is the concept of developing a value chain for mining activities based on a constitution. ${ }^{14}$

The development of mineral resource values through the value chain can only be realized if the policy makers (Government and DPR) have a strong and

Government Regulations and related Ministerial Regulations.

14 Rachman Wiriosudarmo, Kebijakan Pengelolaan Sumber Daya Mineral Berbasis Pasal 33 ayat 3 Undang-Undang Dasar 1945, (Jakarta: Natural Resource Center, 2019), p. 48. 
integrated political

will and

mindset to bring about a multiplier effect in mining governance. ${ }^{15}$ This concept was chosen because it is a logical concept and its design is based on the constitution. In principle, the value chain concept has been adopted in Law no. 4 of 2009, but it has not been implemented properly due to institutional constraints in the authority to execute the policy.

Design the concept of state control that is appropriate to achieve the goals of State Control .

The design of the concept of state control that is appropriate to achieve the goal of state control is through value chain-based mineral resource value development activities. The term value chain can be defined as an increase in added value to natural resources in the downstream sector or often referred to as downstream. Value chain can also be interpreted as a chain of benefits, not only in the downstream sector, but also there must be benefits from the upstream process and side benefits. Value chain thinking was introduced by Micheal Porter, which is a micro concept within the scope of the company to achieve competitiveness. ${ }^{16}$ This thinking has

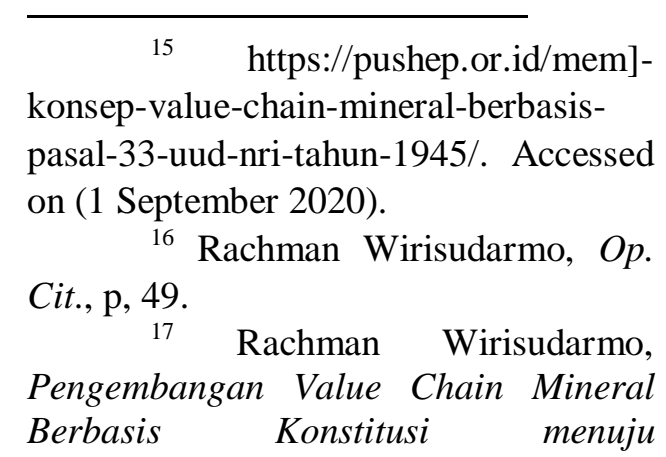

developed and is widely implemented in the development of natural resources, namely providing benefits to the people.

\section{The value}

chain concept consists of supply chain, other economic sectors, support industry, mineral processing industry, and fabricaton and manufacture industry. ${ }^{17}$ The entire system can have an effect on economic growth and improvement, human development, development of local resources, and development of the capacity of the workforce and regional development in general. This usefulness illustrates the existence of a continuous process in mineral resource management and has comprehensive implications. Thus the purpose of natural resource management can be felt by the people.

This concept requires parameters to measure readiness and during the process of implementation. These parameters are in the form of a planned and sustainable grand design of regulations or policy frameworks. In this grand design, one must have a mechanism instrument for analyzing readiness and methods of anticipation in its application. The

\footnotetext{
Industrialisasi Indonesia di Masa Depan.Jakarta, Juni 2020.Makalah dipresentasikan dalam diskusi interaktif virtual dengan tema "Kebijakan Pengelolaan Sumber Daya Mineral Berbasis UUD NRI Tahun 1945" di Pusat Studi Hukum Energi dan Pertambangan pada 29 Juni (2020).
} 
entire policy framework must be owned by policy makers.

The development of mineral resource values can be done by referring to concepts and strategies. According to Rachman Wiriosudarmo, the concept and strategy of developing the value of mineral resources will lead to the goals of the welfare state. To achieve this, a mineral mining industrialization strategy is needed. The strategy for developing mineral industrialization requires Indonesia to become an industrialized country. Thus the mindset and policy direction that is developed must lead to the order of the industrialized state. The concept used to achieve mining industrialization must refer to an idea called the mineral value chain.

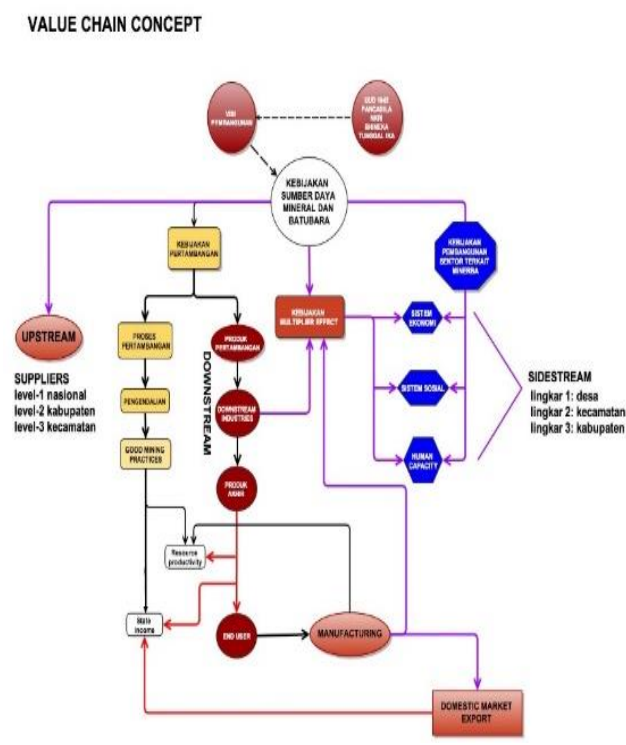

The following is the value chain concept scheme according to Rachman Wiriosudarmo. ${ }^{18}$

\section{Design about State}

When referring to the concept of the right of state control to achieve the purpose of state control through the development of value-based mineral resources value chain, then the design setting its reference to the political laws are integrated to deliver $a$ multiplier effect in the governance of mining. This concept requires the existence of $a$ grand design increase the added value that pe ng rules of his or planned and sustainable policy framework. In this grand design, one must have a mechanism instrument for analyzing readiness and anticipatory methods in its application. In addition, there must also be parameters to measure readiness and during the implementation process. The entire policy framework must be owned by policy makers.

The regulation of the concept of state control that is appropriate for achieving the goal of state control is to optimize policies for increasing added value. The increase in added value resulted from the processing and refining of mineral and coal mining products. The authority in charge of this policy is the synergy between the authority of the Ministry of Energy and Mineral Resources (KESDM) and the Ministry of Industry.

From the regulatory aspect, the concept of state control through activities to increase added value through processing and refining activities must also be integrated. The phrases for processing and refining

${ }^{18}$ Ibid. 
must also go hand in hand, not separately as regulated in Law no. 3 of 2020. If the phrases for processing and refining are still in line, as regulated in Law no. 4 of 2009, the improvement activities can be optimal. Processing activities are carried out and refining activities are also carried out. Unlike the case with the provisions in Law no. 3 of 2020 whose policies are given as an option.

So the main key in regulating state control to achieve the goal of state control is that there must be a strong legal

and institutional substance and have a vision

for Indonesia's industrialization in the future.

\section{CONCLUSION}

The setting is the concept of state control has not diakomod a man in value adding activities as stipulated in Law No. 3 of 2020 . Even the right to control the state as interpreted by the Constitutional Court tends to be ignored. Design setting against the concept of the right of state control to achieve the purpose of state control is the need to have a legal and institutional aspects of the substance that is strong and has a vision of Indonesia in the future industrialization. The substance of the law must refer to the mandate of Article 33 paragraph 3 of the 1945 Constitution and the sustainable institutional management model.

\section{REFERENCES}

Sihombing, Eka N.A.M., Eksistensi Paralegal dalam Pemberian Bantuan Hukum bagi Masyarakat Miskin (The Existence of Paralegals in Providing Legal Aid to the Poor), Jurnal Ilmiah Penegakan Hukum,Vol. 6, No. 1, June(2019).Hadita, Cynthia., Regional Autonomy Political Politics Of Regional Liability Reports To Regional Representatives In The Implementation Of Local Government, Nomoi Law Review, Volume 1, Issue 1, May 2020, p. 91.

Wiriosudarmo, Rachman. Kebijakan Pengelolaan Sumber Daya Mineral Berbasis Pasal 33 ayat 3 Undang-Undang Dasar 1945, (Jakarta: Natural Resource Center, 2019), p. 48.

Wirisudarmo, Rachman. Pengembangan Value Chain Mineral Berbasis Konstitusi menuju Industrialisasi Indonesia di Masa Depan.Jakarta, Juni 2020.Makalah dipresentasikan dalam diskusi interaktif virtual dengan tema "Kebijakan Pengelolaan Sumber Daya Mineral Berbasis UUD NRI Tahun 1945" di Pusat Studi Hukum Energi dan Pertambangan pada 29 Juni (2020).

Zoelva, Hamdan. Memaknai Putusan MK No. 111/PUU-XIII/2015 Tentang Ketenagalistrikan. Disampaikan saat acara Focus Group Discussion (FGD) Kologium Jurist Institute, Hotel Grand Sahid Jakarta, 8 Mei 2019 https://pushep.or.id/memlkonsep-value-chain-mineralberbasis-pasal-33-uudnri tahun-1945 /, 2019. 
Constitutional Court Decision No.001-021-022 / PUU-I / 2003 on Testing

Constitutional Court Decision Number 10 / PUU-XII / 2014 concerning Testing

Constitutional Court Decision Number 3 / PUU-VIII / 2010 concerning Testing

Constitutional Court Decision Number 36 / PUU-X / 2012 concerning Testing

Law No. 22 of 2001 on Oil and Gas of the Act

Law No. 4 of 2009 about Mineral and Coal Mining

Law Number 22 Year 2001 regarding Oil and Natural Gas against the 1945 Constitution

Law Number 27 of 2007 concerning Management of Coastal Areas and Small Islands against the Basic Law.

Law No. 4 of 2009 concerning Mineral and Coal Mining against the 1945 Constitution Academic Paper Bill about Amendment Act

List of Problem Inventory (DIM) of Draft Law on Amendments on Law No. 4 of 2009 concerning Mineral and Coal Mining in 2019 